\title{
PEMBUATAN MEDIA PEMBELAJARAN DIGITAL INFOGRAFIS BAGI GURU SDN SUSUKAN O7 DAN O6 JAKARTA DI ERA SCHOOL FROM HOME
}

\author{
Roslaini $^{1}$, Cahya Komara ${ }^{2}$, Widi Sriyanto*3 \\ ${ }^{1,2}$ Program Studi Pendidikan Bahasa Inggris, Universitas Muhammadiyah Prof. Dr. HAMKA \\ ${ }^{3}$ Teknik Grafika, Politeknik Negeri Media Kreatif \\ : roslaini@uhamkaac.id ${ }^{1}$, cahya.komara@uhamka.ac.id ${ }^{2}$, widi.sriyanto@polimedia.ac.id ${ }^{3}$
}

\begin{abstract}
ABSTRAK
Abstrak: Kegiatan Pengabdian Kepada Masyarakat (PKM) ini bermitra dengan Sekolah Dasar Negeri Susukan 06 dan 07 Jakarta Timur. Tujuan pengabdian ini adalah untuk memberikan pelatihan pada guru-guru SDN Susukan 06 dan 07 mengenai pembelajaran digital infografis agar dapat membantu mereka dalam proses pembelajaran jarak jauh School from Home (SFH) yang sudah ditetapkan oleh pemerintah pada tahun ini. Banyak guru yang belum terampil membuat dan menggunakan berbagai aplikasi digital untuk membuat media pembelajaran digital untuk membantu proses pembelajaran jarak jauh atau School from Home (SFH), dan mereka kurang memiliki pengetahuan tentang media pembelajaran digital; salah satunya infografis. Setelah mengikuti pelatihan media pembelajaran digital khususnya media infografis, para guru sudah mampu membuat dan mendisain media infografis untuk berbagai mata pelajaran, seperti: olah raga, biologi, IPA dan lain-lain. Hal ini dibuktikan dengan hasil karya para peserta pelatihan yang sangat baik. Harapannya para guru-guru yang sudah terlatih akan mampu meningkatkan kualitas pembelajaran di sekolah. Mereka mampu memilih dan merancang serta memanfaatkan aplikasi digital yang sesuai dalam proses pembelajaran jarak jauh School from Home (SFH) sehingga guru bisa menyajikan materi yang menarik dan berkualitas sehingga dapat memacu semangat dan kreativitas peserta didik.
\end{abstract}

Kata Kunci: Digital learning; School from home; Learning media

Abstract: This Community Service Activity (CSA) is in partnership with the Susukan 06 and 07 East Jakarta Elementary School. The aim of this service is to provide training for SDN Susukan 06 and 07 teachers on digital learning of Infographic so that they can help them in the School from Home (SFH) distance learning process that has been set by the government this year. Many teachers are not yet skilled at creating and using various digital applications to create digital learning media to help the distance learning process or School from Home (SFH), and they lack knowledge of digital learning media; one of it is infographic. After participating in digital learning media training, especially infographic media, the teachers have been able to make and design infographic media for various subjects, such as: sports, biology, science and others. This is evidenced by the excellent work of the training participants. The hope is that teachers who have been trained will be able to improve the quality of learning in schools. They are able to select and design and utilize appropriate digital applications in the School from Home (SFH) distance learning process so that teachers can present interesting and quality material so that it can stimulate the enthusiasm and creativity of students.

Keywords: Digital learning; School from home; Learning media

\section{A. LATAR BELAKANG}

Saat wabah COVID-19 ini muncul seluruh aktivitas manusia dibatasi, termasuk kegiatan pembelajaran baik di jenjang sekolah dasar sampai jenjang perkuliahan mulai menerapkan kegiatan belajar dari rumah. Hal ini dilakukan guna membatasi penyebaran virus yang masif. Kebijakan belajar dari rumah mulai diterapkan pada tanggal 9 Maret 2020 setelah menteri Pendidikan dan Kebudayaan mengeluarkan surat edaran nomor 2 tahun 2020 dan nomor 3 tahun 2020 tentang pembelajaran secara daring dan bekerja dari 
rumah dalam rangka pencegahan penyebaran Corona Virus Disease (COVID-19) (kolom.tempo.co, 25 Juni 2020).

Sejak mewabahnya pandemi COVID-19 dan sampai saat ini pun belum berakhir, Kementerian Pendidikan dan Kebudayaan tetap memprioritaskan sistem pembelajaran jarak jauh atau School from Home (SFH). Hal ini berdampak pada kegiatan belajar mengajar di sekolah. Yang lebih prihatin lagi anak-anak didik merasa bosan belajar di rumah, mereka merasa jenuh dengan sistem belajar jarak jauh yang ada, ungkap Seto Mulyadi. (news.detik.com, 22 Juni 2020).

Wakil Presiden Ma'ruf Amin mengakui pemerintah dilematis ketika hendak memberlakukan kebijakan membuka kembali kegiatan mengajar dan mengajar di sekolah umum maupun madrasah. Sebab pembukaan sekolah di tengah wabah virus corona (Covid-19) saat ini terkait dengan perlindungan kesehatan masyarakat (cnnindonesia.com, 25 Juni 2020). Artinya, kegiatan belajar siswa akan masih dilakukan secara daring (online).

Dampak dari proses belajar secara daring ini tampaknya belum memuaskan masyarakat khususnya peserta didik dan juga orang tua. Dari berbagai sumber media masa diketahui bahwa banyak orang tua mengeluh karena merasa anak-anak mereka merasa dirugikan karena anak-anak tidak belajar selayaknya dan tidak dapat menyerap pelajaran dengan baik. Mayoritas peserta didik hanya diberi tugas melalui alat bantu yang sederhana, seperti WhatApps atau video. Dari sini dapat diketahui bahwa para guru belum memiliki pengetahuan yang memadai untuk melakukan pembelajaran secara daring, dengan kata lain, pembelajaran jarak jauh atau School from Home (SFH).

Kegelisahan peserta didik dan orang tua ini dikuatkan oleh adanya kerisauan guru di lapangan. Menurut salah satu sumber berita, Koran Tempo, menyatakan bahwa hampir mayoritas guru di Indonesia merasa kebingungan dalam melaksanakan proses pembelajaran jarak jauh School from Home (SFH) ini. Hal ini dibenarkan pula oleh Unifah Rosyidi, Ketua Umum Persatuan Guru Republik Indonesia (PGRI), bahwa panduan pelaksanaan pendidikan yang diberikan pemerintah pada masa pandemi Covid19 ini belum menjawab masalah yang muncul dalam sistem belajar jarak jauh School from Home (SFH). Di DKI Jakarta, gubenur Anies Baswedan, pun masih memberlakukan pembelajaran jarak jauh atau School from Home (SFH) menunggu sampai keadaan benarbenar aman dan kondusif.

Kondisi yang sama juga dihadapi oleh guru-guru Sekolah Dasar Negeri Susukan 06 dan Sekolah Dasar Negeri Susukan 07 (SDN Susukan 06 dan 07) Jakarta. Jumlah guru di kedua sekolah ini sekitar 34 orang. Dari diskusi dengan kepala sekolah Ibu Nurul Huriyah, S.Pd dan beberapa guru SDN Susukan 06 dan 07 Jakarta diperoleh informasi bahwa sebagian besar guru belum memiliki keterampilan yang cukup dalam merancang pembelajaran digital (digital learning) untuk membantu proses pembelajaran daring di masa School From Home (SFH) ini. Dalam proses pembelajaran guru masih terbatas pada penggunaan WhatsApp, google meet, dan Video dalam proses pembelajaran. Guru belum terampil dalam merancang dan memanfaatkan media teknologi untuk digital learning seperti media infografis.

Media seperti infografis ini demikian sejatinya sangat diperlukan dalam proses pembelajaran di masa pandemi ini dimana proses pembelajaran dilakukan secara jarak jauh School from Home (SFH). Media infografis adalah sebuah media yang dapat memvisualisasikan data atau ide dengan mencoba menyampaikan informasi yang kompleks kepada audiens dengan cara yang dapat dengan cepat namun mudah dipahami (Smiciklas, 2012). Banyak ahli atau praktisi yang telah mengungkapkan manfaat atau keuntungan menggunakan media infografis dalam konteks Pendidikan seperti oleh Naparin dan Saad (2017) dimana kemampuan literasi murid menjadi meningkat serta menyenangkan siswa secara tampilan visual. Selain itu, (Apriyanti dkk 2020) menegaskan bahwa hasil riset need analysis tim mereka mengungkap bahwa media 
infografis sangat dibutuhkan dalam bidang pengajaran dan pembelajaran. Hal ini menunjukan betapa baiknya keterampilan membuat media infografis apabila dikuasai oleh guru di SDN susukan 06 dan 07. Sayangnya, guru-guru belum memiliki keterampilan tersebut. Padahal, guru-guru dapat dengan mudah membuatnya dengan bantuan website penyedia jasa desain yaitu Canva.com.

Mencermati kondisi seperti di atas, kami tim pengabdian dari Universitas Muhammadiyah Prof. Dr. Hamka memiliki tanggung jawab terhadap proses pendidikan di Indonesia untuk membantu pemerintah. Dengan adanya Catur Darma Perguruan Tinggi memungkinkan para civitas akademika untuk membantu program pemerintah agar berjalan dengan baik. Maka pada kesempatan ini, kami tim dosen FKIP UHAMKA ingin menyelenggarakan kegiatan yang dapat membantu terealisasinya program pemerintah. Kami ingin melaksanakan kegiatan pelatihan yang dapat membantu guru dalam proses pembelajaran jarak jauh School from Home (SFH) berupa pelatihan pembelajaran digital infografis yang akan dilakukan secara daring di SDN Susukan 07 dan 06 Jakarta.

\section{B. METODE PELAKSANAAN}

Mengacu pada permasalahan mitra yaitu dimana guru-guru menghadapi permasalahan terkait dengan pembelajaran jarak jauh atau School from Home (SFH) di era pandemi covid-19 ini, maka perlu memberikan keterampilan tambahan pada guruguru khususnya di bidang teknologi media digital infografis guna membantu guru dalam melakukan proses pembelajaran di sekolah agar lebih efektif.

Guru-guru yang diberikan pelatihan adalah guru SDN Susukan 07 dan 06 Jakarta Timur. Kegiatan pelatihan ini dilakukan oleh para tim pelaksana yang berkompeten dalam bidangnya. Tim pelaksana terdiri dari tiga orang dari program studi Pendidikan Bahasa Inggris yaitu Dr. Roslaini, M.Hum selaku ketua tim pelaksana kegiatan pengabdian masyarakat sekaligus Narasumber 1, Widi Sriyanto, M.Pd sebagai Narasumber 2 di bidang teknologi pembelajaran dari Politeknik Negeri Media Kreatif, dan Cahya Komara, M.Hum selaku anggota tim pelaksana sekaligus host/moderator. Ketua tim pelaksana dibidang ilmu Bahasa Inggris dan linguistik. Anggota tim Cahya Komara, M.Hum dibidang ilmu Bahasa Inggris, ICT/computer, serta linguistik. Kegiatan berlangsung sebanyak 2 kali secara daring melalui zoom meeting pada hari Sabtu tanggal 8 Agustus dan 15 Agustus 2020.

Penyampaian materi menerapkan metode ceramah yaitu bentuk pemaparan lisan secara langsung atau tidak langsung (Sudjana; 2010). Tim pelaksana terlebih dahulu menyebar kuesioner sebagai isntrumen untuk mendapatkan input atau informasi (Cohen, Manion, \& Marrison, 2007) terkait status awal pemahaman media infografis guru SDN Susukan 07 dan 06 Jakarta Timur. Kemudian, pelatihan diberikan dan ditutup dengan menyebar kuesioner kembali untuk mengecek output dari pelatihan yang diadakan. Berikut ini jadwal kegiatan daring yang dilakukan:

\begin{tabular}{|c|c|c|c|c|}
\hline No & Tanggal & Waktu & Materi & Narasumber/Pelatih \\
\hline 1 & $\begin{array}{l}8 \text { Agustus } \\
2020\end{array}$ & $\begin{array}{l}09.00- \\
12.00\end{array}$ & $\begin{array}{l}\text { Media } \\
\text { Pembelajaran; dan } \\
\text { Praktek pembuatan } \\
\text { Media Infografis }\end{array}$ & $\begin{array}{l}\text { Dr. Roslaini, M.Hum; } \\
\text { Widi Sriyanto, M.Pd }\end{array}$ \\
\hline 2 & $\begin{array}{l}15 \text { Agustus } \\
2020\end{array}$ & $\begin{array}{l}09.00- \\
12.00\end{array}$ & $\begin{array}{l}\text { Presentasi hasil } \\
\text { karya guru-guru }\end{array}$ & $\begin{array}{l}\text { Widi Sriyanto, M.Pd; } \\
\text { Dr. Roslaini, M.Hum }\end{array}$ \\
\hline
\end{tabular}

\section{HASIL DAN PEMBAHASAN}




\section{a. Pelatihan Pembuatan Media Infografis}

Pada pertemuan pertama, Narasumber 1, Dr. Roslaini, M.Hum, menyajikan materi tentang media pembelajaran guna memberi penyegaran pada guru-guru mengenai arti pentingnya media dalam proses pembelajaran khususnya dalam proses pembelajaran daring, hal ini meliputi: pengertian media, jenis-jenis media, dan media visual. Di bawah ini gambar penyajian pertama oleh narasumber pertama pada hari pertama tanggal 8 Agustus 2020.
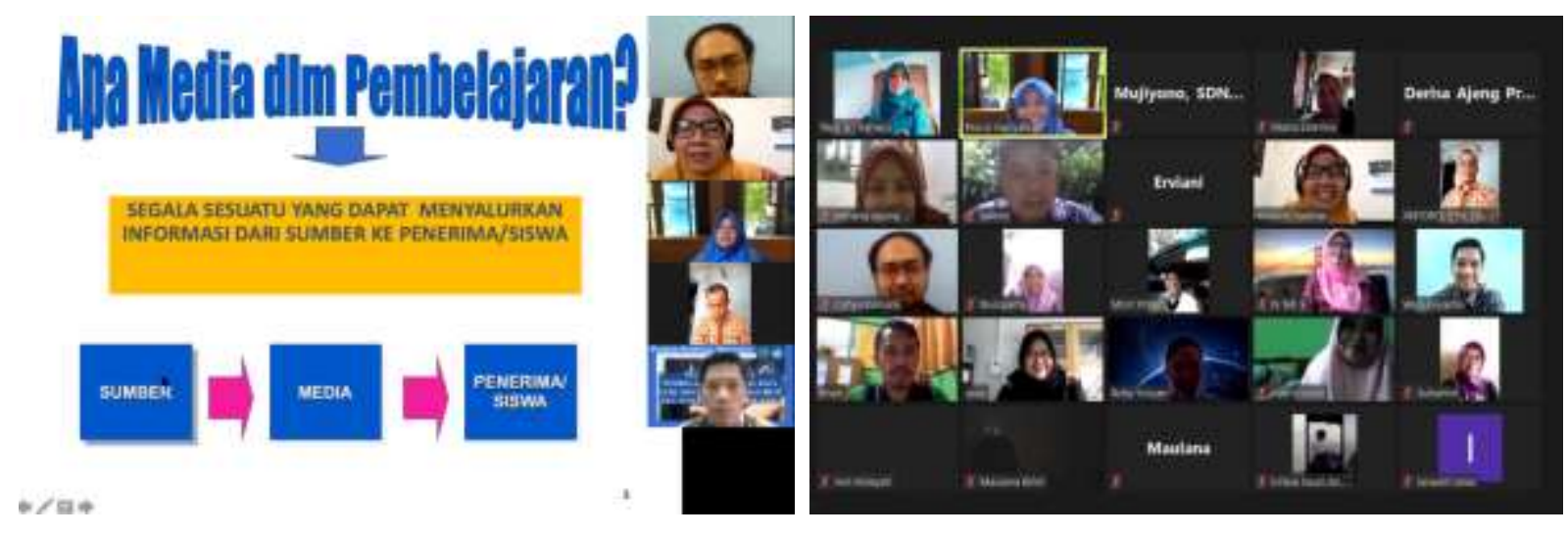

\section{Gambar 1 dan 2}

Penyampaian Materi 1 oleh Dr. Roslaini, M.Hum Tanggal 8 Agustus 2020

Pada kegiatan hari pertama ini, peserta hadir sebanyak 26 orang, 16 orang dari SDN Susukan 07 dan 10 orang dari SDN Susukan 06 Jakarta. Mereka semua khidmat mengikuti kegiatan pelatihan ini. Para peserta boleh bertanya jawab dengan narasumber terkait hal-hal yang belum dipahami oleh para peserta pelatihan. Setelah selesai, maka kegiatan dilanjutkan dengan materi 2 yang akan dipandu oleh bapak Widi Sriyanto, M.Pd.

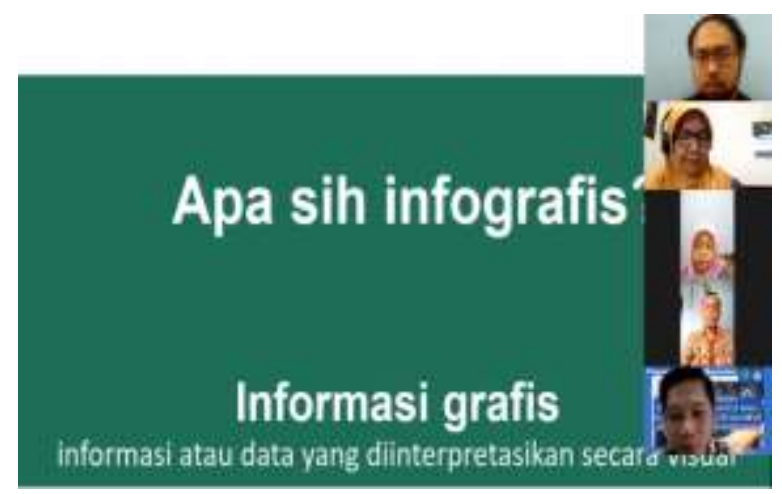

Gambar 3 dan 4

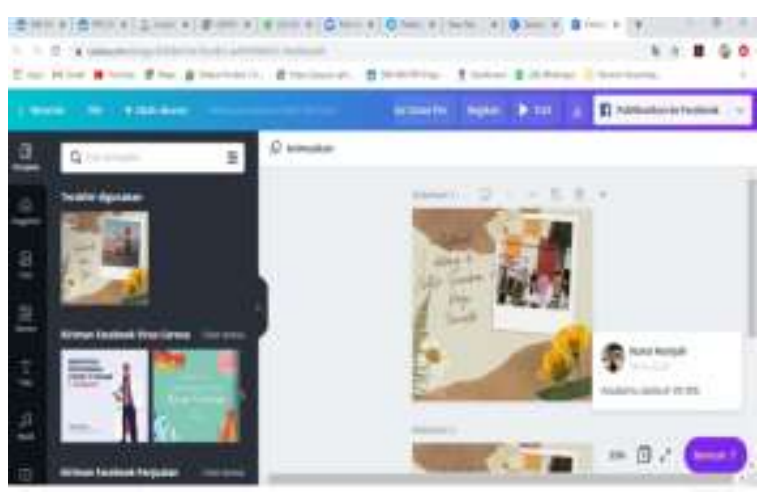

Penyampaian Materi 2 oleh Widi Sriyanto, M.Pd Tanggal 8 Agustus 2020

Bapak Widi Sriyanto dalam hal ini memberikan pengetahuan kepada para peserta pelatihan mengenai media Infografis yang meliputi: pengertian infografis, cara membuat infografis, kegunaan infografis, dan jenis-jenis infografis. Setelah para peserta memiliki pengetahuan yang cukup tentang infografis lalu dilanjutkan dengan praktek membuat infografis. Para peserta pelatihan melakukan pelatihan sambil berdiskusi langsung dengan narasumber. 

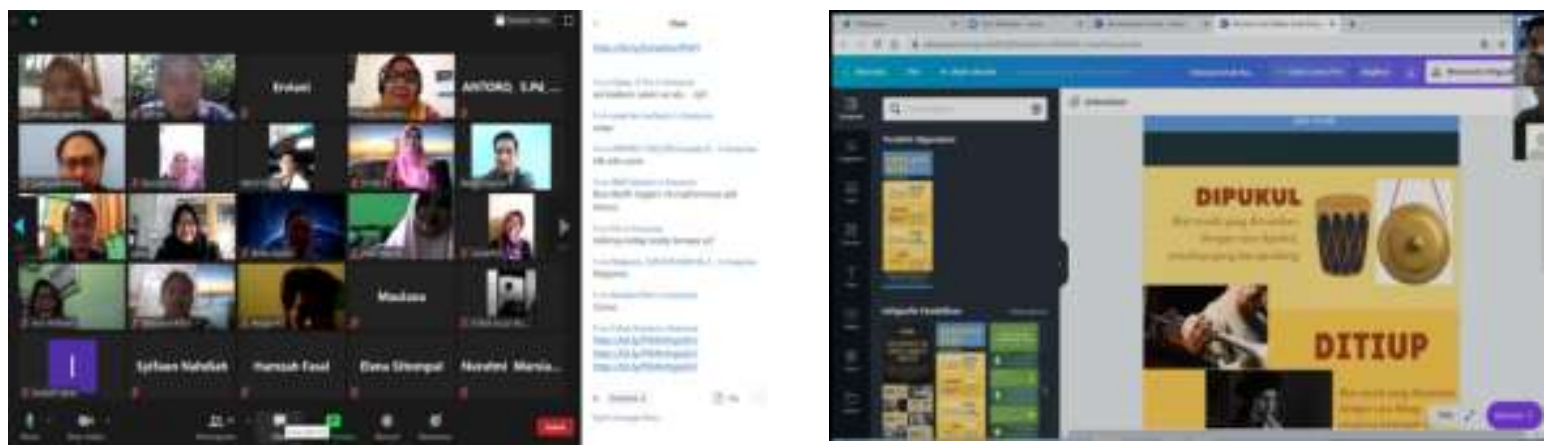

Gambar 5 dan 6

Peserta Berlatih Pembuatan Infografis

Pada tanggal 15 Agustus 2020, peserta melanjutkan aktifitas membuat karya media infografis dan menyajikannya secara verbal. Berikut ini hasil-hasil karyanya;
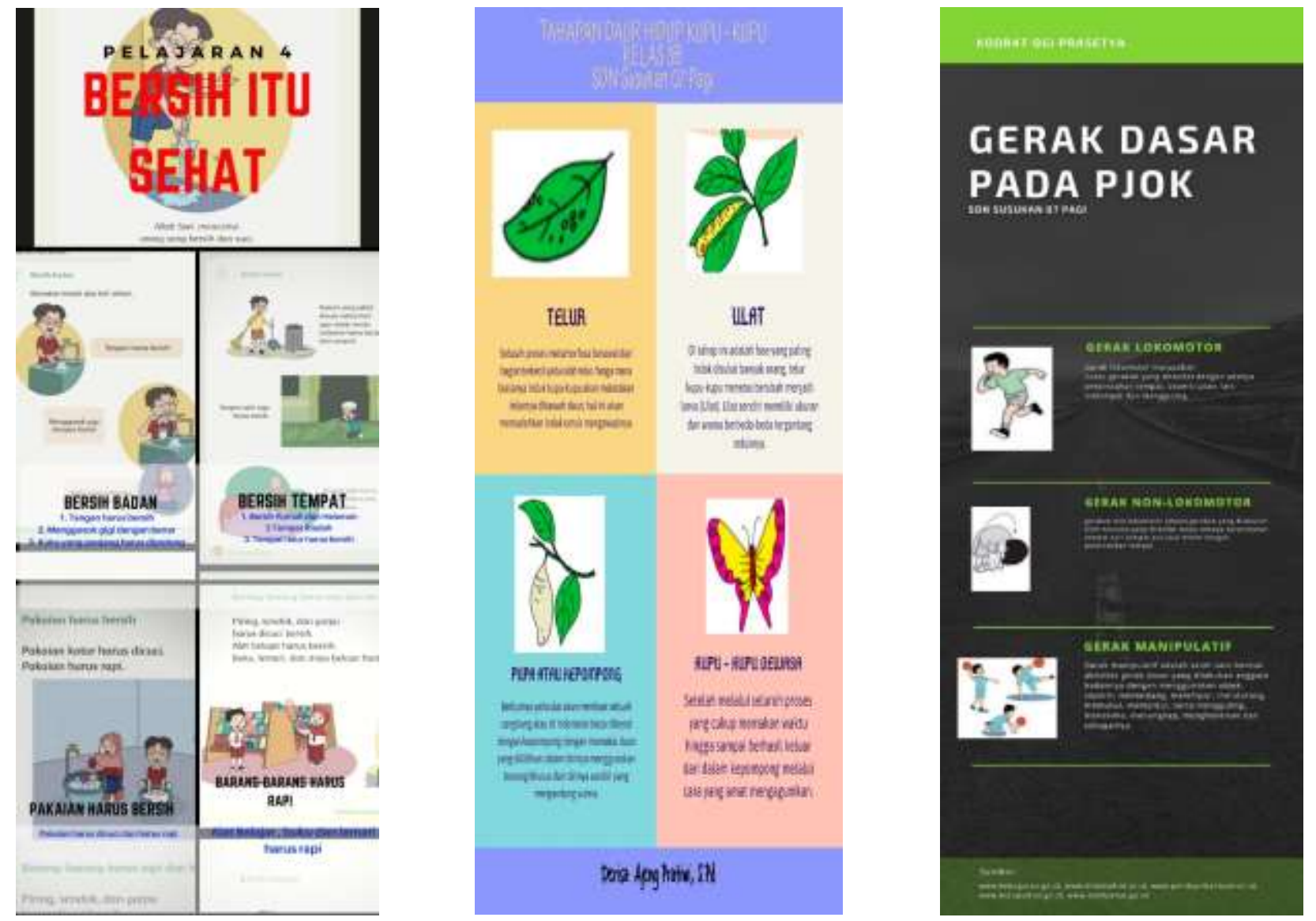

\section{b. Hasil Angket}

\section{1) Hasil Angket Awal}

Angket awal digunakan untuk mengetahui seberapa jauh para peserta guru memiliki pengetahuan tentang media pembelajaran digital khususnya media infografis. Hal ini bertujuan agar narasumber dapat mengetahui kemampuan awal para peserta. Dari hasil angket dapat diketahui bahwa dari 26 peserta guru terdapat 73,1\% guru kelas dan 
26,9\% guru mata pelajaran; 53,8\% mengajar di kelas tinggi dan 46,2\% mengajar di kelas rendah. Berikut gambaran keadaan guru menurut Pie Chart:

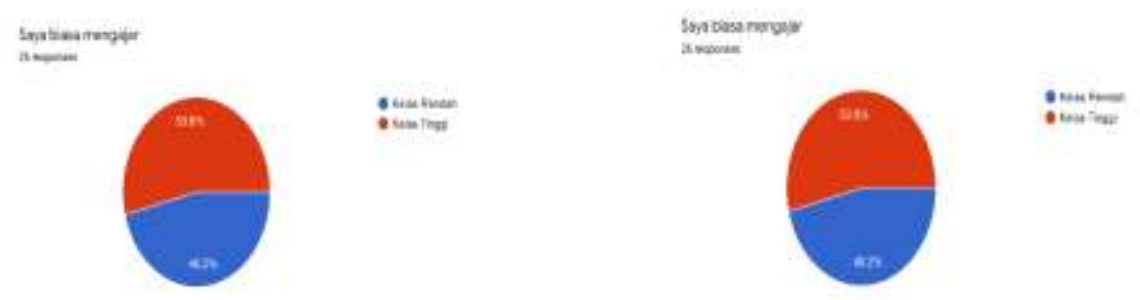

\section{Diagram 1. Guru di SDN Susukan 07 dan 06}

Selanjutnya, mengenai pengetahuan para guru tentang teknologi diperoleh informasi bahwa mayoritas guru kurang/tidak mengetahui bahwa banyak Learning Management System (LMS) yang bisa digunakan untuk membantu pembelajaran, sehingga sebagian besar belum mampu menerapkan dalam pembelajaran karena kesulitan dalam menggunakan teknologi tersebut. Untuk gambarannya dapat dilihat dari Bar Chart di bawah ini;

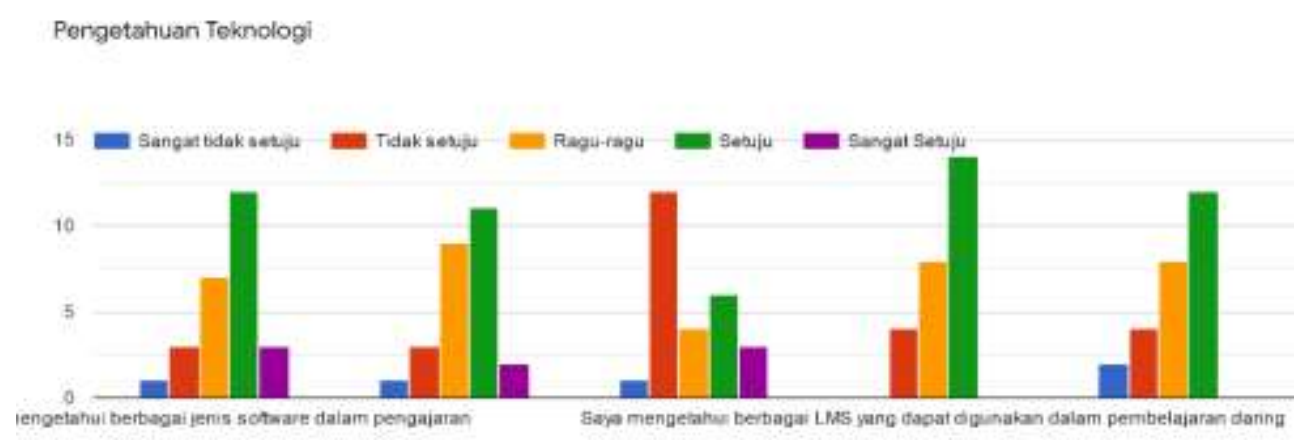

Kebiasaan Penggunaan Teknologi

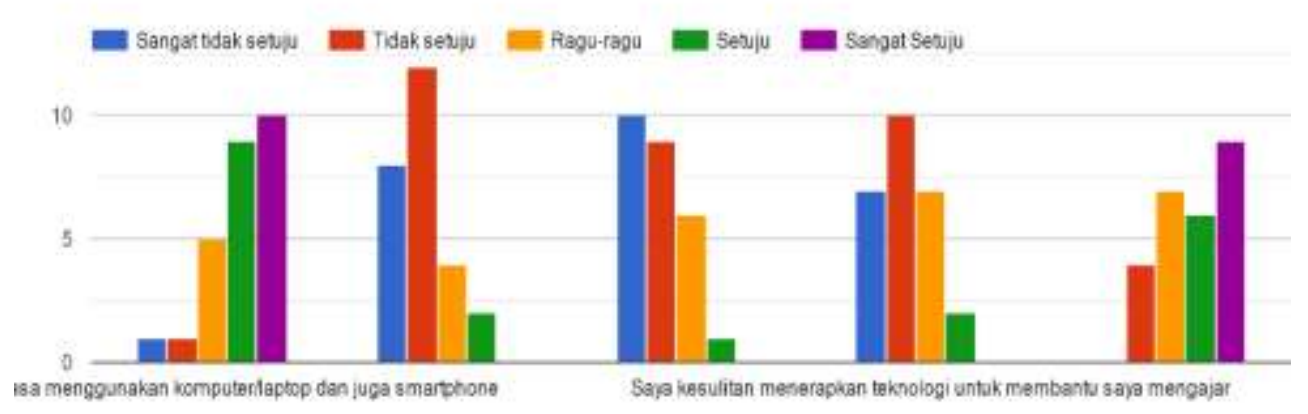

Selain itu, kemampuan para peserta guru dalam membuat bahan ajar sudah cukup baik, namun belum memiliki kemampuan menggunakan berbagai aplikasi LMS dalam pembelajaran daring/online.

\section{2) Hasil Angket Akhir}

Setelah pelatihan selama 2 hari, alhamdulillah dari hasil angket akhir dapat diketahui keberhasilan dari para peserta guru dalam mengikuti pelatihan media 
pembelajaran digital ini dimana para guru merasa ilmu dan pengetahuannya bertambah setelah mengikuti pelatihan. Hal tersebut dapat dilihat dari jawaban peserta melalui Bar Chart di bawah ini.

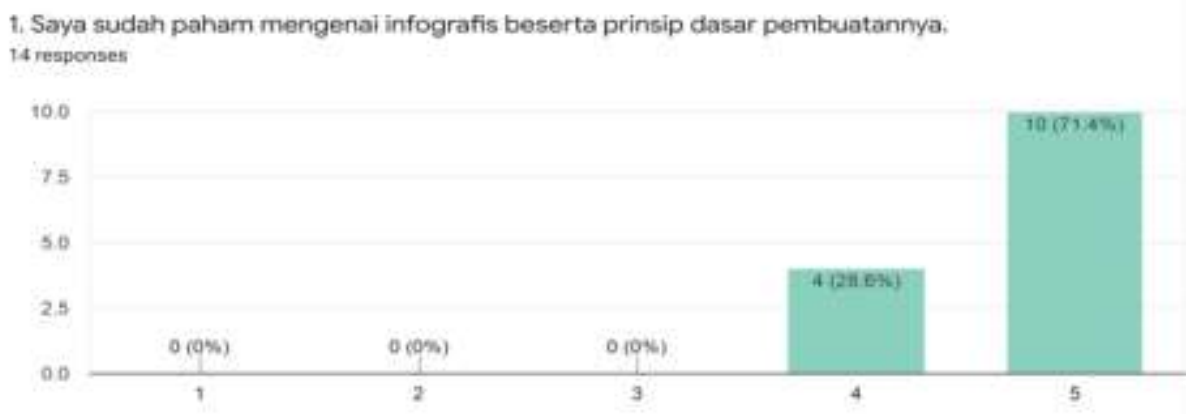

Lalu para peserta guru pun sebagian besar sudah mampu membuat infografis seperti terlihat dari jawaban angket dalam Bar Chart di bawah ini.

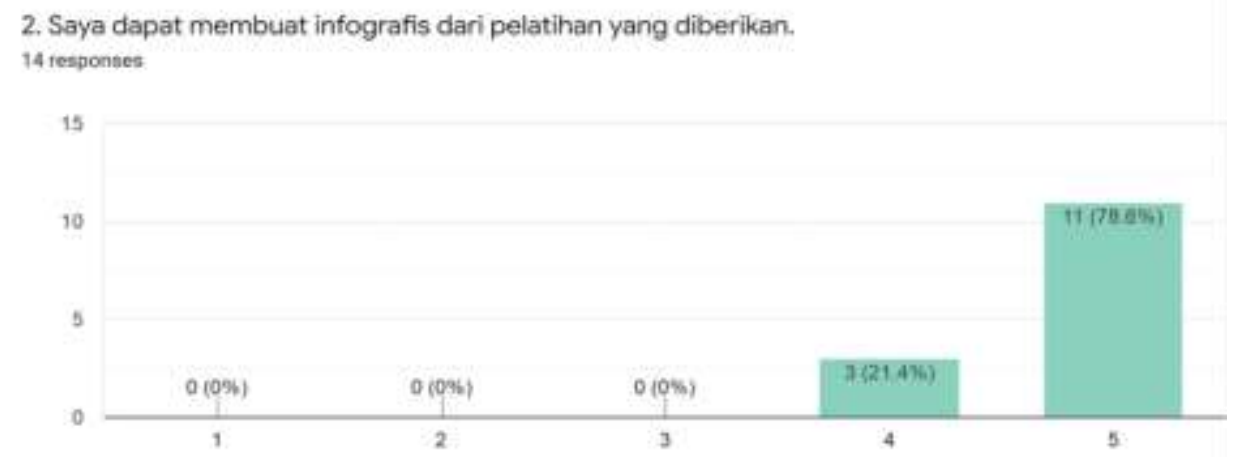

Yang sangat membanggakan dari hasil pelatihan media pembelajaran digital ini adalah bahwa para peserta guru merasa mendapat ilmu baru dari pelatihan media infografis ini. Artinya, sebelum pelatihan media pembelajaran digital ini banyak dari para peserta guru hanya memanfaatkan alat bantu seadanya seperti WhatsApp Group dan video dari youtube. Jawaban dari angket di bawah ini membuktikan bahwa para peserta guru merasakan manfaat dari pelatihan ini yaitu mengenai media pembelajaran digital yang memanfaatkan teknologi dimana mereka dapat menerapkannya dalam pembelajaran di kelas atau melalui daring/online. Ini jawabannya dapat dilihat dari Bar Chart di bawah ini.

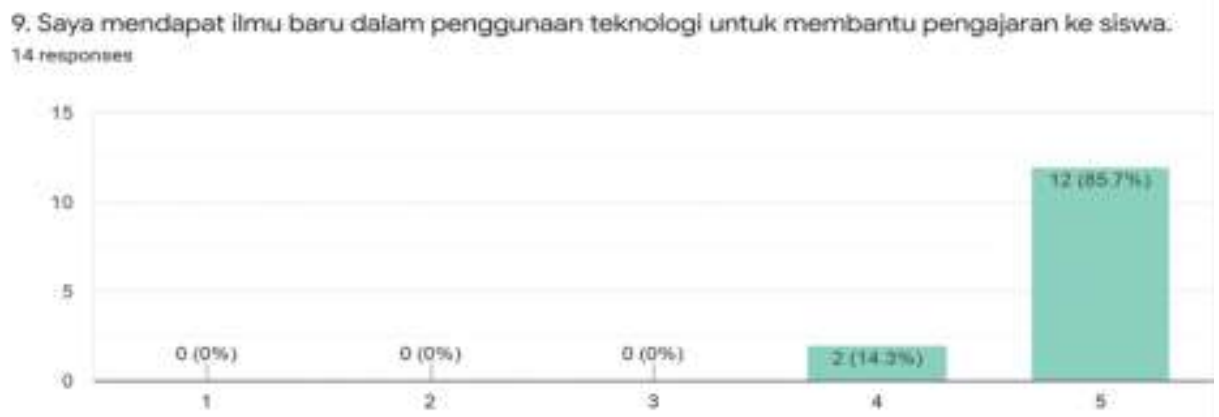

Jadi, dari hasil angket awal diketahui bahwa para peserta guru belum memiliki ilmu pengetahuan dan pengalaman yang cukup tentang pemanfaatan teknologi dalam proses pembelajaran. Mereka merasa kesulitan dalam membuat dan merancang media pembelajaran yang efektif dalam mengajarkan materi kepada siswa-siswinya. Nah, 
setelah pelatihan para peserta guru menjadi lebih paham dan kreatif dalam membuat dan menyiapkan media pembelajaran yang efektif dan menarik untuk siswa-siswi khususnya untuk siswa Sekolah Dasar.

\section{SIMPULAN DAN SARAN}

Hasil pengabdian pada masyarakat yang telah dilaksanakan oleh tim kami, menunjukkan bahwa terjadi penambahan pengetahuan dan keterampilan para peserta pelatihan yaitu guru-guru SDN Susukan 07 dan 06 dalam menguasai pembuatan media pembelajaran digital khususnya media infografis. Para peserta pelatihan yang awalnya belum begitu paham terhadap berbagai aplikasi Learning Managemnet System (LMS) dan belum maksimal memanfaatkannya dalam proses pembelajaran di sekolah. Alhamdulillah, setelah para peserta mengikuti pelatihan media pembelajaran digital khususnya media infografis, mereka sudah mampu membuat dan mendisain media infografis untuk berbagai mata pelajaran, seperti: olah raga, biologi, IPA dan lain-lain. Harapannya guru-guru yang sudah terlatih akan mampu meningkatkan kualitas pembelajaran di sekolah. Dari hasil angket awal dan hasil angket akhir menunjukkan bahwa ada peningkatan pengetahuan dan keterampilan sehingga berdampak pada para peserta dimana mereka sudah mampu membuat dan mendisain media infografis untuk pembelajaran di sekolah. Hal ini dibuktikan dengan hasil karya para peserta pelatihan yang sangat baik.

Diharapkan peningkatan kemampuan dalam penguasaan teknologi khususnya untuk pengajaran dan pembelajaran dapat terus dilakukan, agar para guru dapat memenuhi tuntutan perkembangan zaman yang serba digital saat ini.

\section{UCAPAN TERIMA KASIH}

Tim penulis mengucapkan terima kasih kepada Lembaga Pengabdian Pada Masyarakat (LPPM) Universitas Muhammadiyah Prof. Dr. Hamka yang telah mendanai kegiatan pengabdian ini sehingga terlaksana dengan baik.

\section{DAFTAR RUJUKAN}

Apriyanti, N., Shaharom, M. S. N., \& Abdul Razak, R. (2020). Needs Analysis Of Infographic Media Using Technology for Learning Physics. Malaysian Online Journal of Educational Technology, 8(1), 48-62.

Cohen, L., Manion, L., \& Morrison, K. (2007). Research method in education. Oxon: Routledge. Naparin, H., \& Binti Saad, A. (2017). Infographics in Education : Review on Infographics Design. The International Journal of Multimedia \& Its Applications, 9(4/5/6), 15-24.

Nugroho, T. T. (2020). Pembelajaran jarak jauh dimasa pandemi. Jakarta: Indonesia. Retrieved June 25 2020, from http://kolomtempo.co.

Putri, I. (2020). Anak-Anak mulai bosan pendidikan jarak jauh?. Jakarta: Indonesia. Retrieved June 22, 2020, from http://news.detik.com.

Saputra, R. R. (2020). Ma'aruf soal pembukaan sekolah: ini dilema pemerintah. Jakarta: Indonesia. Retrieved June 25 2020, from http://cnnindonesia.com.

Sudjana, N. (2010). Dasar-dasar proses belajar. Sinar Baru: Bandung.

Smiciklas, M. (2012). The power of infographics. New York: Pearson Education. 